кУЛЬтУрологИя

\author{
АНТИНАТАЛИЗМ В ДРЕВНЕГРЕЧЕСКОЙ КУЛЬТУРЕКАК ПРОТИВОСТОЯНИЕМ ДВУХ \\ НАЧАЛ (К ПОСТАНОВКЕ ПРОБЛЕМЫ)

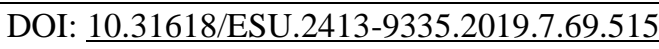 \\ Научный руководитель \\ Лыкова Наталия Николаевна \\ Кандидат культурологии, \\ доцент кафедры гуманитарных и сочиально-экономических дисииплин \\ Крымского филиала ФГБОУВО «Российский государственный университет правосудия» \\ Умрихин Дмитрий \\ студент 108-Б группы \\ факультета непрерывного образования по подготовке специалистов для судебной системы \\ Крымского филиала ФГБОУВО «Российский государственный университет правосудия»
}

\title{
ANTINATALISM IN ANCIENT GREECE'S CULTURE AS A CONFRONTATION OF TWO PRINCIPLES (TO THE PROBLEM STATEMENT)
}

Lykova Nataliya Nikolayevna
candidate of culturological sciences, docent of the Crimean branch of the Federal state budget educational institution of higher professional education

"Russian state University of justice" $+79788270746$

Dmitry Umrikhin student of the 108-B group of the faculty of continuing education for training specialists for the judicial system of the Federal state budget educational institution of higher professional education

"Russian state University of justice"

\section{АННОТАЦИЯ}

В данном материале предоставлен философский анализ культуры Древней Греции с позиции этические ценности, что рассматривает деторождение как неэтичный поступок и преступление против жизни. Принято изображать древнегреческую культуру в каком-то неповторимом ореоле чистого чувства, искреннего и прекрасного. В действительности, культура античного периода была наполнена, как красотой, так и уродством: противостоянием двух начал - природного и человеческого. Автор делает вывод о том, что данная философская концепция проходит через века и является предтечей христианской мысли.

Основные понятия статьи: антинатализм, дихотомия в культуре, этическая позиция, философская концепция, интерес, высокое искусство, Ренессанс, преступление против жизни, предтечей христианской мысли.

\section{SUMMARY}

This article presents a philosophical analysis of the culture of Ancient Greece from the standpoint of ethical values, which considers childbirth as an unethical act and a crime against life. It is customary to depict ancient Greek culture in a unique aura of pure feeling, sincere and beautiful. In fact, the culture of the ancient period was filled with both beauty and ugliness: the confrontation of two principles - natural and human. The author concludes that this philosophical concept passes through the centuries and is the forerunner of Christian thought.

Basic concepts of article: antinatalism, dichotomy in culture, ethical position, philosophical concept, interest, high art, Renaissance, crime against life, forerunner of Christian thought.

Анализ научной проблемы: тема этичности деторождения актуальна как никогда из-за роста прогрессивных идей с середины прошлого века в Европе. Активно можно наблюдается дискуссия об абортах и в защиту прав и здоровья женщины. Антинатализм являлся однозначно оживленной темой для обсуждения в Европе под влиянием Артура Шопенгауэра. Но мало, где рассматривается вопрос антинатализма в Древней Греции культуре как противостоянием двух начал. Культура эллинов является образцовой в вопросах философии, точных наук и искусства, но почему-то не принято рассматривать “темную” сторону, хаотическую часть древнегреческой культуры.

Основной материал: Для интеллигенции Европы увлечение греческой культурой, наукой и философией не ново со времен Ренессанса. Принято изображать древнегреческую культуру в каком-то прекрасном ореоле чистого, искреннего и прекрасного, но в действительности, культура греков была наполнена, как красотой, так и уродством: противостоянием двух начал природного и человеческого. 
Оба этих начала нашли выражение в двух божествах греческого пантеона - Дионисе и Аполлоне. Традиционно принято изображать первого как бога вина, но в контексте статьи мы будем ассоциировать его с природой, ужасом жизни и её иррациональностью. Второго же, как бога солнца, что будет играть роль созидательных качеств человеческой культуры, надежды и всего, что принято называть "прекрасным.

Но “культура-это всего лишь тоненькая кожура над раскаленным хаосом”.

Дионис показывает весь ужас жизни, с которым сталкивается человек, это буйство без причины, хаос и страдание, что просто есть, как и природа, Дионис просто существует. Эти нотки экзистенциализма, скорее, ближе к Камю, чем к какому-то либо другому философуэкзистенциалисту, ведь именно он и ставил главным фактом то, что человек страдает без причины, не ради чего-то достойного, а просто от того, что он жив.

Поклонники Диониса запивали эту горечь жизни вином, участвовали в оргиях, что совсем неважно для моего исследования, ведь для христиан, которыми были, по большей мере все авторы экзистенциальной мысли, такой способ борьбы со страданием мерзок.

А Аполлон постулирует все хорошее в человеке: веру, разум в основе жизни и прогресс. Мысль о том, что искусство существует лишь благодаря любви и красоте рождается в человеке от Аполлонского начала души и искреннего благородства.

Но Бог создал не только агнца, что невинен и чист, но ещё и тигра - и в этом противостоянии жестокого и ужасающего, и чистого и непорочного. В этом и состоит основной конфликт не только культуры, но и души каждого человека. И эта борьба рождает искреннею печаль и грусть, ведь для человека торжество чистого и прекрасного всегда должно быть непрекословным абсолютом. Эта печаль прослеживается в греческой культуре, как ни в какой другой, но вместе с ней рождается красота и любовь.

Греческая культура полна печали потому, что какой другой народ смог бы передавать через поколения сказания о Силене, что является первой предпосылкой к антинаталистической мысли, или миф о Сизифе, что станет краеугольным камнем философии французских экзистенциалистов.

Антинатализм - это этическая концепция того, что деторождение неэтично само по себе, ведь жизнь полна страданий и печали. Довольно популярна данная позиция среди пессимистов. Но это не значит, что все антинаталисты разделяют мнение того, что следует отказаться от рождения вообще и дать полную свободу абортации, в действительности, многие являются ярыми борцами с абортами и однозначными пролайферами. (Ведь страдание рождает красоту, что будет описано ниже).

Рассмотрим же образчик первой антинаталистической мысли, миф о Силене.
Повествование говорит о том, как царь Мидас пытался изловить одного из слуг Диониса, Силенафавна. И, наконец, поймав его, Мидас спросил, что лучшее для человека. Фавн долго молчал, но затем с хохотом ответил: "Злополучный однодневный род, дети случая и нужды, зачем вынуждаешь ты меня сказать тебе то, чего полезнее было бы тебе не сльишать? Наилучшее, что есть для тебя вполне недостижимо: не родиться, не быть вовсе, быть ничем. А второе по достоинству для тебя - скоро умереть".

Греческий миф наполнен страхом перед природой и существованием, что иллюстрировано этим преданием, ведь Силен - посланник Диониса, m. е имеет божественное начало, и он, потешаясь, рассказывает о том, что участь человеческая страдание в чистом виде. И страшно откровение это потому, что оно неожиданно от того, кто должен был быть посланником бога разгула и праздной веселости.

И таким страхом пропитана вся культура Древней Греции, а все величие их искусства попытка побега от тягостного существования. Но тогда появляется вопрос? Могла бы существовать культура без страха перед жизнью? - Однозначно нет, ведь страдание стало причиной рождения искусства. И жизнь - это не только ужас, но и настоящая красота, и красота эта так прекрасна изза страдания и ужаса, что без противоречия красота и страх стали бы лишь пресностью, а пресность худшее, что может статься с культурой.

Если вспоминать даже эпические поэмы Гомера, то можно вспомнить то, как страшна природа в “'Одиссеи'”: Все те создания мифов, всякие чудища и т.д., есть метафорой на боязнь природы, не только дикой, но и человеческой. Разве миф о Тантале, где отец убивает своего сына, а затем приносит в жертву Богам, за что и был наказан на вечные муки. А данной ситуации ужасающим чувством выступает человек, а не природа.

В одном из последних фильмов «Антихрист» Ларс фон Триер через уста главного персонажа выдал крайне ценную фразу о том, что в его понимании Рай и Ад - одно и тоже. Этой фразой можно обозначить и греческую культуру, где в качестве райского понимания выступает вера в прогресс. Надежда и философия - все это вроде бы и есть богатство греческой культуры, но адское оно всегда есть и всегда будет.

Ницше делает упор на то, что культура рождается именно в противостоянии чуда и ужаса, но, что торжество христианства в Европе доказывает обратное: боязнь жизни рождает чудо, человек даже готов пойти на муки из надежды одной и веры, а вспомним и о диониссийском начале: гедонизм - стал, порицаем, чревоугодие принял опыт греха. Но значит ли это перевес аполлонского перед диониссийским?

Даже если не вспоминать христианскую мораль, то можно прийти к идеи того, что страдание есть предтеча красоты. 
Выводы и перспективы дальнейших исследований: Антинатализм как элемент культуры не потерял своей ценности и ныне. Так как в настоящий день культура сталкивается с проблемой неискренности. Не искренности во всех её проявлениях, где красота сбрасывает чувственную окраску. Ирония к живому, настоящему и неподдельному - вот новый главный виток юмора как призмы искусства современности. И как раз таки и антинатализм является элементом новой искренности.

Список использованных источников и литература:
1.Асмус, В. Ф. Античная философия /В.Ф. Асмус. М.: Высш. шк., 2001.-400 с.

2.Басов, Р.А. История древнегреческой философии от Фалеса до Аристотеля / Р.А. Басов. М.: ЗАО «Издательский Дом «Летопись ХXI», 2002.-415c.

3.Гаязов, Р.А. Культура это взаимосвязь творчества, духовности и души / Р.А. Гаязов // Гуманистический потенциал культуры и ее роль в модернизации Российского общества, матер, межвуз. науч.конф. - Казань: КГАКИ, 2002.-С.3740.

4. Гайденко П.П. История греческой философии в ее связи с наукой / П.П. Гайденко.СПб.: Университетская книга, 2000.319 с. 